\title{
QUEEN'S
QNEIVERSITY
BELFAST
}

\section{Mobile Borders and Turbulent Mobilities: Mapping the Geopolitics of the Channel Tunnel}

Zhang, C. (2019). Mobile Borders and Turbulent Mobilities: Mapping the Geopolitics of the Channel Tunnel. Geopolitics, 24(3), 728-755. https://doi.org/10.1080/14650045.2017.1379994

\section{Published in: \\ Geopolitics}

\section{Document Version:}

Peer reviewed version

Queen's University Belfast - Research Portal:

Link to publication record in Queen's University Belfast Research Portal

\section{Publisher rights}

(C) 2017 Taylor \& Francis.

This work is made available online in accordance with the publisher's policies. Please refer to any applicable terms of use of the publisher.

\section{General rights}

Copyright for the publications made accessible via the Queen's University Belfast Research Portal is retained by the author(s) and / or other copyright owners and it is a condition of accessing these publications that users recognise and abide by the legal requirements associated with these rights.

Take down policy

The Research Portal is Queen's institutional repository that provides access to Queen's research output. Every effort has been made to ensure that content in the Research Portal does not infringe any person's rights, or applicable UK laws. If you discover content in the Research Portal that you believe breaches copyright or violates any law, please contact openaccess@qub.ac.uk. 


\title{
Mobile borders and turbulent mobilities: mapping the geopolitics of the Channel Tunnel
}

\author{
Chenchen Zhang (chenchen.zhang@qub.ac.uk)
}

\begin{abstract}
This article investigates the making and contestation of mobile borders around the Channel Tunnel, the fixed link connecting Britain and the European continent. It suggests that the bordering of the infrastructural and vehicular spaces is both an object of inquiry in its own right and a productive lens for reflecting on questions related to EU territory, the heterogeneous nature of borders as well as the interplay between regimes of control and resistance. The paper starts by reviewing the legal and institutional frameworks in which the Channel Tunnel area is governed and envisioned as an interstate and European/Schengen borderzone. It then examines the uncoordinated efforts of national, private and European authorities in managing the episodic migration controversies around this area, which bring together the interconnected rationales of security, economy and humanitarianism and expose the dissonance between and within them. Finally, the article considers how the acts of turbulent mobilities interact with this contingent assemblage of mobility governance and realise the radical potential of territorial borders.
\end{abstract}

'Breakfast in Brussels, lunch in London, dinner in Paris.'

-- Metropolitan, Eurostar's onboard magazine

'Terrorists' fast train to Britain: Mail exposes shocking security flaws that allow ANYONE to get to the UK on Eurostar without a passport'

-- Headline of a Daily Mail story ${ }^{1}$

\section{Introduction}

Throughout its conception, construction and operation, the Channel Tunnel fixed link connecting Britain and the European continent has been at the centre of longstanding controversies over regional development, geopolitical identity, and more recently border security ${ }^{2}$. Especially from 1999 onwards, the tunnel itself, the passenger and freight trains through it as well as the transit migrant camps in Sangatte and Calais have all become an integral part of the public imagination of border 'problems' on both sides of the English Channel ${ }^{3}$. At the height of the European refugee 'crisis' in 2015, the reported number of attempts to enter the Channel Tunnel facilities in Calais seemed so alarming that 'majorities' of French and British respondents would support 'sending the British Army in to Calais' according to an opinion poll ${ }^{4}$. In fact, the hybrid and continuous space encompassing the railway stations, the infrastructural network as well as the vehicles constitutes borders not only in imaginative and representational ways, but also in concrete institutional and geophysical terms. It is in this space where mobile and 'mobility-dependent' ${ }^{5}$ bordering practices, regulated by an array of institutional arrangements and conditioned by its geophysical characteristics, take place. However, although the Anglo-European rail link has been examined by political and economic geographers, previous studies have focused mainly on issues such as 
national legal identity and cross-border regional development, rather than the processes that construct the rail link and the space it generates as mobile borders. On the other hand, scholars of border and migration studies have looked at the politics of sovereign exclusion, humanitarian government and migrant activisms in Sangatte and Calais ${ }^{6}$, without paying much attention to how specific institutional and material conditions shape the simultaneously de- and re-territorialising effects of the Anglo-European and Schengen border.

The making (and unmaking) of this borderzone deserves a closer scrutiny not only because it is undoubtedly one of the 'hotter' ones in Europe - few others convey such contradictory images ranging from frequent travellers' lounges, cosmopolitan-spirited on-board magazines to electrified fences, 'jungle'-like makeshift camps and desperate journeys as it does, but also because it offers a unique prism through which to reflect on broader discussions on EU territoriality, the polysemic nature of borders as well as the relationship between bordering practices and the turbulent mobilities that exceed it. The field of critical border studies has over the last decades advanced a 'processual shift' ${ }^{7}$ that views borders no longer as taken-for-granted and stable objects but as 'manifold and in a constant state of becoming' ${ }^{8}$. Challenging conventional understandings about who does borderwork and where borders are, this scholarship has proposed to study borders in terms of bordering practices carried out by different state and non-state actors at and far away from the territorial edge. The disaggregated and 'fluid' dimensions of borders have been further elaborated on through the concept of borderscapes, which emphasises that borders are at once established and 'continuously traversed by a number of bodies, discourses, practices and relationships' involving endless negotiations of identities and boundaries ${ }^{9}$. In other words, the multiplicity of borders not only refers to the fact that borders are produced at multiple sites, 'dispersed a little everywhere' ${ }^{10}$ in various political, legal, and socioeconomic processes, but also recognises that these processes are themselves highly contested, fragmented and constitutive of alternative border imaginaries. One of the key problematics in the transformation of borders is the nexus of security and mobility: diffused, networked and outsourced modalities of bordering practices are organised around the central task of facilitating transnational flows of circulation while at the same time identifying, preventing or slowing down unwanted mobilities that are perceived as a security problem ${ }^{11}$. Investigating the security/mobility nexus requires not only analysing the governmental regimes and technologies policing and regulating the movement of people and things, but also accounting for the ambivalent relationship between regimes of control and strategies of resistance without assuming one 'comes before' the other ${ }^{12}$.

This paper builds on and contributes to these overlapped strands of literature in border and mobility studies by examining the tensions and disjunctions in the multi-sited production of the Channel Tunnel as a European and Schengen borderland that is both fixed, 'traditional' - located at territory's edge, and mobile, centred on enabling smooth and secured mobility. I contend that it makes a particularly productive case study in several ways. First, the geopolitical positioning of the tunnel at the internal borders of the European Union (EU), external frontiers of the Schengen area ${ }^{13}$, and as a fundamental infrastructural project of a European border region implies that the mobility- 
dependent bordering practices are situated in and expressive of different legal and normative constellations. Exploring the tensions and conflations between these frameworks enables us to better comprehend the manifold nature of borders as well as the 'overlapping, competing and uncoordinated ${ }^{14}$ principles involved in governing the nexus of security and mobility. Secondly, as geographers have accentuated the inseparability of mobility and its immobile 'moorings' ${ }^{15}$, researchers of borders and security have also started to pay more attention to the physical infrastructures and other materials - such as vehicles, roads, maps and 'deserted' objects ${ }^{16}$ - of human mobility. Walters for example argues that 'the material properties of the mode of transportation' is crucial to understanding how vehicles and their systems define 'limits and possibilities for migration politics'. ${ }^{17}$ Along these lines, the case in question offers a unique opportunity to illuminate how the specificities of (immobile) rail infrastructures and (moving) trains not only become integral to visual and discursive representations of borders, but also, together with the multiplicity of legal regimes and political rationales, impact upon the limits of border policing and possibilities for resistance. Thirdly and relatedly, a geopolitical reading of the Channel Tunnel as effectively the actual territorial border also allows us to reflect on the radical potential of territoriality and its relation to mobility politics.

Approaching borders as both juridico-political and geophysical constructs, this article aims to investigate the uncoordinated ways in which various institutional, representational and geophysical forces participate in the crafting of mobile borders along the Channel Tunnel and interact with the struggles of turbulent mobilities. Inspired by Cresswell and Martin's discussion of turbulence, I refer to illegalised and often violent journeys across the English Channel as turbulent mobilities: they are turbulent as they follow unpredictable and spontaneous iterations, interrupting the orderly systems of mobility both literally - by causing for example temporary suspension of train service and lorries stuck in motor ways - and figuratively, by putting the exclusionary logic of the entire border regime into question. If the notion of turbulence highlights the 'entanglements of disorder and order' and 'makes visible the always-contingent orderings of infrastructural mobilities' ${ }^{18}$, then the rationales, discourses and organising logics of bordering are also characterised by heterogeneity and contingency. As Cooper and Perkins have argued, bordering as a 'practical activity' involves overlapping processes in which state and private actors 'draw upon different sources of legitimacy - or rule structures - in order to frame, produce and resist borders', and the processes form a 'fragile assemblage of actors, rules and objects' ${ }^{19}$. Both this fragility of the assemblage of competing rules and logics and the material properties of mobility - in this case the geophysical site containing and constituted by railroads, stations and vehicles - are instrumental to the politics of resistance that takes the form of turbulent mobilities.

While aware of the importance of everyday and routinised practices that take place at the border ${ }^{20}$, this article has chosen to focus on discursive, institutional and material bordering projects at macro- and meso- levels. In so doing it seeks to foreground that borders at the Channel Tunnel are 'performed into being, ${ }^{21}$ not only by the everyday policing of the infrastructural and vehicular spaces there, but also through institutional and representational practices done elsewhere: in 
national and EU laws, parliamentary debates, popular press, transnational solidarity activisms and so forth. Therefore, although the article has benefited from observations and conversations made in nodal points such as Calais and London St Pancras Station, the analysis draws mainly from a range of archival materials including international treaties, legal proceedings, public speeches and media narratives. Critical security scholars have argued that speech-acts do not 'simply describe an existing security situation' or represent a border crisis, but 'bring it into being' by 'successfully representing it as such" ${ }^{22}$. Similarly, these textual and visual discourses bring the moving borders into being through a plurality of spatial imaginaries that are not limited to that of sovereign security. They also reflect the actual or perceived conflicts between the interests and calculations of different actors.

The first part of the article reviews the legal and institutional frameworks in which the Channel Tunnel area is governed and envisioned as an interstate and European/Schengen borderzone. The first section examines the international treaties that lay down the legal grounds for frontier controls on the new Anglo-French border, and section 2 illuminates how the border-making projects merge two contrastive visions of EU territory, and challenge the dichotomous framing of the European space as either fortress-like or cosmopolitan, or a combination of the two designated to the edges and centres separately. The article then analyses the responses of national, private and European authorities to the episodic migration controversies around the Channel Tunnel at length. Both utilising and circumscribed by the material properties of the infrastructures, vehicles and routes, these uncoordinated efforts constitute a fragile assemblage of mobility governance that constantly discloses the dissonance between and within the interconnected rationales of security, economy and humanitarianism. Finally, the article considers how attending to these institutional and material specificities helps us better understand the ambivalent relationship between the regimes of border/mobility control and the politics of border/mobility struggles.

\section{Setting the scene I: the legal framework for the Channel Tunnel}

The first joint statement approving construction of a fixed link between Britain and mainland Europe was announced by British and French leaders in 1966, but the project was then unilaterally abandoned by the British government in the 1970s amidst the economic crisis. It was not until 1981 that the Channel Tunnel project was officially revived by then British Prime Minister Thatcher and French President Mitterand; and as Sparke has observed ${ }^{23}$, the trend of regionalisation in the context of European integration provided a major impetus for the renewed interest in this century-old idea. The treaty authorising the construction of the tunnel and establishing its governance structure, known as the Treaty of Canterbury, was finally concluded between the UK and France in 1986. A supplementary Concession Agreement awarded a 55-year concession (extended to 99 years in 1997) to Eurotunnel, a private company, for building and operating the tunnel. Although the Treaty itself did not include provisions on concreate measures concerning border and immigrant controls, Art. 4 described the general principle as 'the frontier controls shall 
be organised in a way which will reconcile, as far as possible, the rapid flow of traffic with the efficiency of the controls, 24 .

Provisions for frontier controls and policing became the subject of the Sangatte Protocol, signed by the British and French governments in $1991^{25}$. The Protocol reiterated the general purpose of 'simplifying and speeding up' (Art. 5) the formalities related to entry and exit, and established accordingly the so-called 'juxtaposed controls': a set of arrangements to enable French border authority to set up checkpoints at Cheriton in Kent and British authority to operate at Coquelles in France. These arrangements would be later on extended to include Belgium through a tripartite agreement. Critical to the implementation of juxtaposed controls is the notion of 'control zone' (zone de contrôles), defined in the Protocol as 'the part of the territory of the host State' within which 'the officers of the adjoining State are empowered to effect controls'. More specifically, control zones include terminal stations of the cross-channel rail link and the trains, where officials of the other contracting party are authorised to carry out checks (Art. 1). However, although the original Protocol mentioned that states may 'agree to an extension of the control zones for through trains, as far as London and Paris' (Art. 7), as such this agreement did not extend control zones to other stations beyond each end of the tunnel itself. After the passenger train service started to operate in 1994, the absence of pre-embarkation passport control on persons was believed to have contributed to what was referred to as a 'loophole'. British politicians claimed that 'for several years, people trying to enter our country without adequate documentation' had 'been misusing the Eurostar service' ${ }^{26}$. In an attempt to close this 'loophole', the two parties signed an Additional Protocol in 2000, which established pre-embarkation immigration control bureaux at all the terminal stations served by Eurostar in both countries ${ }^{27}$. This instrument explicitly states that authorities of the state of arrival shall have extraterritorial power in these control zones to check 'whether the person is in possession of the necessary travel documents and fulfils the other conditions for entry to its territory' (Art. 3). Crucially, the Additional Protocol provides that the responsibility to process asylum claims lies with the state of departure if such claims are made during a control, after 'the person has passed through this control and before the train doors close'. The responsibility nevertheless shifts to the state of arrival after the train doors have closed (Art. 4).

These international agreements hence lay down the legal framework for the hybrid space of governance engendered by the Channel Tunnel, built to 'bridge' the natural maritime border, to function, somewhat paradoxically, as moving borders. Central to this framework is the introduction of juxtaposed controls as a form of extraterritorial immigration control ${ }^{28}$. As Shah has pointed out, the practice of extraterritoriality has always been a constitutive element of territorial sovereignty. Extraterritorial practices reinforce, rather than undermine, the juridico-political dimension of territory through mutually recognising and legitimating the extension of sovereign power beyond the 'traditional' territory. In other words, the physical dimension of territory is 'legally modified' to 'carve out spheres of sovereign authority' ${ }^{29}$. The definition of 'control zones' provided in the Sangatte Protocol is illustrative of this legitimation work which extends the state's juridical power outside its physical territory while at the same time reaffirms territorial jurisdiction as the basis of 
authority. In the context of immigration controls, extraterritorial bordering practices through the employment of offshore detention centres, 'preventative' interventions and pre-clearance arrangements enable the state to police its borders and detect unwanted mobilities far away from its frontiers. In comparison with these other 'technologies of extraterritorialisation' ${ }^{30}$, however, the arrangements of policing and surveillance in the space of the Channel Tunnel are exceptionally territorial - they take place at the extended frontier where one has access to a fixed and indeed highspeed link to the territory of the state of arrival. In this sense control zones at the stations and on moving trains are effectively the physical borders between sovereign states. The antinomy between speed and security, closure and connectivity, fixity and motion is played out in this particular combination of legal and geophysical settings that bring about a border space that in a way embodies 'traditional entry points', but of which the primary purpose is to connect and transport, instead of fixing or delimiting. The arrangements of juxtaposed control and the conflation between the physical frontier and the transportation network reinforce the exclusiveness of territory as jurisdiction on one hand, and amplify the connective capability of territory as geographical space on the other.

Another significant point about the legal framework is the ambiguous status of Eurotunnel and the relationship between the concessionaries and the governments in managing security and frontier controls. On the one hand, although policing and immigration controls are carried out by state authorities, Eurotunnel is responsible for constructing the 'buildings and installations necessary for frontier controls'. The private company shall also 'ensure the continued flow of the traffic in the Fixed Link under satisfactory safety conditions', and 'that all necessary steps are taken to permit the steady flow and continuity of traffic' through the tunnel ${ }^{31}$. On the other hand, Article 2(2) of the Treaty provides that the governments must 'adopt such legislative and regulatory measures, and take such steps, as are necessary for the construction and operation of the Fixed Link' by the concessionaires. In short, Eurotunnel and the governments ought to take joint responsibilities for the 'normal' operation of the transport network and for ensuring the exercise of police and frontier controls. As to be shown in Section 3, however, these provisions also give all actors leeway to ignore their responsibilities and play a blame game when turbulent mobilities disrupt the 'stead flow' of traffic. A final noteworthy feature of this set of international agreements is that although made between national governments and private concessionaires, as Darian-Smith has pointed out, the jurisdiction of EU law necessarily 'lurks in the background' ${ }^{32}$. For example, the construction and operation of the tunnel shall comply with relevant Community rules, such as freedom of movement, and the 'facilitations of controls and administrative formalities' shall be pursued in accordance with relevant directives ${ }^{33}$. On this note, we now move on to explore in more detail the 'EUropean' dimensions of the Channel Tunnel that are not limited to the influence of EU legislation in the background. The border-making project is also profoundly associated with two ostensibly competing projects of EU territory epitomised by the Schengen space and cross-border regionalism. 


\section{Setting the scene II: when Schengenland meets Euroregion}

The scholarship on the restructuring of borders and territoriality in Europe have typically presented two contrastive imageries with regard to its 'internal' and 'external' respectively - a 'cosmopolitan' and 'network' Europe centred on connectivity and mobility in which the significance of state borders is diminishing ${ }^{34}$, and a 'Fortress Europe' where borders are reinforced in physical, technological as well as cultural-identitarian terms. ${ }^{35}$ The 'internal' and 'external' borders have also been explicitly framed as fundamentally different and negatively correlated in the official discourse - to the degree that the 'strengthening of the Union's external borders' would be a 'corollary to the abolition of internal borders' ${ }^{36}$. In their analysis of the Draft Constitution of the European Union, Bialasiewicz et al. find that not only borders are considered qualitatively different; one could also identify two distinct narratives of EU territory in this indicative document. They observe an 'aspirational' notion of territory conveyed by the idea of territorial cohesion, which envisions Europe as 'a putative space of values and area of solidarity' ${ }^{37}$. Yet also endorsed therein is an idea of 'hard' territory in the traditional sense of the term, primarily organised around issues of external border control and jurisdictional delimitation. However, although pointing out the distinction between these two types of 'territory' can be analytically useful, we should caution against the dichotomous thinking that serves to naturalize the binaries of internal/external borders and internal/external mobility. Contributions from critical border studies have sought to question this binary, showing that the internal/external differentiation has been socially and politically constructed both in the EU case and in the historical development of national borders ${ }^{38}$. But what seems to remain underexplored is how different geopolitical visions of the European space interact and overlap with one another beyond this constantly reproduced differentiation. Indeed, geographers working on the spatial development agenda of the EU and political scientists studying its multilevel border management regime rarely engage with one another, even though both fields deal with the changing nature of borders and territory in the area. Located in the only European cross-border region which stretches across Schengen borders, the case of the Channel Tunnel is distinctly suitable for the task of not only challenging the binary of cosmopolitan versus fortress Europe, but also engaging a dialogue between these different disciplinary foci.

As the epigraph of this article shows, one could easily consider the transnational transport network and its iconic high-speed passenger train as symbolising a borderless Europe defined by connectivity and hybermobility. A distinct European character has been evident ever since the early stage of the project. While the English side was at the beginning deeply concerned with her endangered national identity in front of all the dangerous things - ranging from rabies to military invasion - that would be brought by the tunnel from mainland Europe ${ }^{39}$, then French president Mitterrand would praise the Tunnel as representing an ever closer community with a single 'nervous system' ${ }^{40}$. Despite the initial resistance and anxiety, the construction of the tunnel was eventually perceived by local leaders as an impetus for further cross-border collaboration, or a 'catalyst for regional economic development' ${ }^{41}$, leading to the establishment of a so-called Euroregion in 1991 comprising Kent, Nord-Pas-de-Calais, and the Belgian regions of Wallonia, 
Flanders and Brussels. In Britain, choosing the 'easterly route' of the high-speed railway also reflected an anticipation of its potential contribution to the regeneration of the Thames Gateway, or the Thames estuary region stretching from East London to Kent and Sussex, including 'some of the most deprived urban areas' in the country ${ }^{42}$. At the EU level, the proliferation of Euroregions in the 1990s was actively promoted as 'the most common form of institutionalised cross-border cooperation' ${ }^{43}$ through structural fund initiatives such as INTERREG. Furthermore, the crossChannel rail network would soon be expanded to include Belgium and become one of the first priority projects in the European Commission's ambitious initiative of Trans-European Transport Network (TEN-T). As the centrepiece of both the Euroregion and the TEN-T, the Channel Tunnel is thus envisioned to play a key role in facilitating cross-border regional cooperation and materialising the 'emergent spatialities" 44 of Europe, which have been described in both official discourses and academic interventions through such catchwords as a 'Europe of regions' and 'network Europe'.

In sharp contrast to this 'postnational' geopolitical imagination is the Schengen border regime that has had an influence on 'all the existing bilateral and multilateral agreements for the management of their frontiers' ${ }^{45}$ in Europe and that has shaped the reterritorialisation of the Channel Tunnel space in a drastically different way. As a consequence of the UK's opting out of the Schengen Agreement, all the major stations in the cross-channel rail network including London St Pancras, Paris Gare du Nord and Brussels Gare du Midi are listed as border-crossing points in the Schengen Borders Code. In other words, the transportation network and the vehicles have become the external borders of the Schengen area, which is built upon a complex set of EU rules and mechanisms of cooperation between national border authorities. In this context, when the bilateral agreement between the UK and France concerning the governance of the tunnel was expanded to include Belgium, there was good reason for the new party to believe that the existing rules on jointly managing the 'control zones' might be in conflict with relevant provisions in the Schengen Agreement, of which both France and Belgium are signatories, and Article 7 of the EC Treaty that provides for free movement of persons within the Community.

Upon the request of the Belgian delegation, therefore, a new article (Art. 27) was inserted to the original Agreement which stated that Community law prevails over the provisions of the Agreement and the Protocol. In addition, the Belgian government made a unilateral declaration claiming that 'the Agreement and the Protocol does not prejudice the willingness of Belgium to implement the Schengen Agreement', and that all control procedures provided by the Schengen Agreement on entry to and exit from Schengen countries shall be applied at the Brussels-Midi station. When ratifying the tripartite agreement and the protocol at the Belgian Federal Parliament, an explanatory memorandum further confirmed that 'while Belgium does not waive its right to carry out checks on board, it has decided that the majority of checks would take place before departure at Brussels-Midi', which must be regarded as an external border of the Schengen area ${ }^{46}$. This anecdote in the drafting of the tripartite agreement prior to the opening of the tunnel is worth mentioning for it exemplifies some of the unique ways the Schengen regime is configured. It first of all foregrounds the discrepancies between EU and Schengen borders resulted from the asymmetrical 
and flexible approach to European integration, though these discrepancies tend to be, intentionally or not, concealed in discursive framings that presume an implicit correspondence between the territory of the Union and the Schengen Area. Depending on the context, Schengen is referred to as 'a territory' or confused with 'territory of the Union' when emphasis is placed on transnational controls of human mobility within and to the $\mathrm{EU}^{47}$. The potential conflict between the intergovernmental agreement on managing cross-border railway mobility and the Schengen regulation further reveals that, as Christiansen and Jørgensen put it, the walls 'around the alleged "Fortress Europe"" are 'erected by individual policies' and they intersect ${ }^{48}$. The Belgian insistance on pre-embarkation and arrival checks at Brussels-Midi reminds us that the borders of Schengen are not only incoherent and variable, but also non-linear, in that they are officially defined by a set of scattered and connected 'crossing-points' such as airports, sea ports and train stations, of which a list must be regularly updated by each Member State ${ }^{49}$. In this sense Schengen borders exemplify, in physical and institutional terms, what has been termed the 'pixelisation of borders' or the shift of borders from lines to 'points of connection' distributed over networks and flows ${ }^{50}$, though these transformations have been previously described only with reference to virtual, biometrical, and thus ubiquitous borders ${ }^{51}$.

The heterogeneous 'rule structures' underpinning the bordering of the Channel Tunnel area tell us more than the ambiguities of the Schengen system. They also reveal that contrasting visions of EU territory and different modalities of border governance are not only correlated, but also practically intertwined in the reconfiguration of certain European border regions as simultaneously 'internal' and 'external'. Studies of border security have analysed the efforts to reconcile free movement and security imperatives in the EU framework of border management ${ }^{52}$. Equally important is to note that the mechanisms of Schengen bordering operate differently in different geopolitical contexts and in connection with other imaginaries, discourses and policy frameworks such as European spatial policy and border regions. In this case, the common thread that connects the Euroregion, the TEN-T and the Schengen visa regime is the envisioning and governance of a European space of frictionless, competitive and secured mobility (and speed), a project itself depending on certain forms of immobility (and slowness). However, the priority of external frontier controls in the Schengen regime and the perspective of economic integration in spatial development inevitably impact on one another in the fragile process of harmonising these competing visions of EU (and state) territory. For instance, it has been pointed out that one of the reasons for relatively low levels of cross-border economic integration in this region, comparing to similar projects such as the Øresund bridge between Denmark's capital region and South Sweden, is that all cross-border movement is subject to passport controls ${ }^{53}$. On the other hand, local, national and European actors are able to draw on discourses of Euroregions, free movement as well as a competitive European rail market to produce a counter-narrative to securitisation. It is against this background of legal and institutional complexities that the next section sets out to examine the contingent and contextdependent ways in which mobile borders are performed in the formation and management of recurrent migration controversies surrounding the Channel Tunnel, Eurostar and the camps. 


\section{From stowaways to loopholes: the making of mobile borders}

As mentioned earlier, the Channel Tunnel and attempted unauthorised crossings have in the past decades been associated with recurrent episodes of security anxiety and humanitarian emergency. The first wave of controversies was focused on the presence of a Red Cross reception centre located in Sangatte between 1999 and 2002, which aroused popular sentiments about 'invasions' of migrants on the British side and gave rise to concerns about humanitarian grievances and public order on the French side ${ }^{54}$. Following a meeting between then British Home Secretary David Blunkett and French Interior Minister Nicolas Sarkozy, the Sangatte centre was closed in 2002. What continued to occupy its proximate geographical area and the public imagination of border threats has been the makeshift camp in Calais known as 'the jungle'. The anxious sentiments associated with the 'abuse' of the Eurostar service reached a climax at the end of 2011, when the so-called 'Lille Loophole' was exposed to public attention. In November 2011, BBC published leaked internal correspondence among the employees of the UK Border Agency (UKBA) which revealed that 'illegal migrants' could enter the UK without going through immigration checks by boarding a train in Brussels with a ticket to Lille, because passport controls were not required for travels within Schengen; nor were they conducted on board or upon arrival. The report specifically provided the details about the following scene:

One UKBA officer describes an incident in April at a Brussels station where he stopped two Iranians who he said "bore all the hallmarks of Lille loopholers".

After they were questioned the Belgian police intervened.

One officer shouted: "This has got to stop. You are not in Britain now, you are in Schengen. If they make a complaint you will be arrested." 55

The publication of this story not only yet again provoked sensationalist narratives in the British media about the vulnerability of the British borders vis-à-vis EU rules, but also led the UK government to demand Eurostar to suspend service in Calais and Lille. After a tripartite meeting held in Brussels in February 2012, the stops at Lille and Calais were resumed, and post-arrival passport checks for passengers travelling from Brussels, Calais and Lille were temporarily introduced at London St Pancras station. Unsurprisingly, in the midst of the Europe-wide refugee 'crisis', the Calais 'jungle' has made headlines in national news on both sides of the channel yet again since 2014, even after its demolition in late 2016.

The highly diverse, unpredicted and multi-sited practices organised around representing and governing the mobility of people and things across the Channel Tunnel bring to the fore inherently contestable meanings of the border - or borderscapes. For Rajaram and Grundy-Warr, the concept of borderscapes provides an entry point from which to study 'practices, performances, and discourses that seek to capture, contain, and instrumentally use the border'. It emphasises that border spaces are not static but 'fluid' and 'disjunctive'; nor are they organised through 'a central body' such as sovereign power, but zones of 'competing and even contradictory emplacements ${ }^{56}$. 
A similar approach has emerged in the studies of mobilities. Salter conceptualises the contemporary mobility regime as an 'assemblage of circulation', which involves technologies of control and facilitation that are not hierarchically organised or monopolisied by state power. They are instead 'rhizomatic, disaggregated, and heterogeneous', bringing together 'overlapping, competing, and uncoordinated efforts to manage circulation, ${ }^{57}$. In this vein, the analysis below is structured around three key, intertwined rationales that are weaved into the representations, performances and discourses seeking to manage migration controversies from the Sangatte centre to the latest 'crisis', namely security, economy - framed in terms of regional integration and competitiveness, and humanitarianism. The border theatre of the Channel Tunnel is thus reflective of similar modes of development in the governance of migration and borders at the EU level, in which the discourses of security, economy and fundamental rights as parameters of migration politics are, in the words of Feldman, wrapped into 'an integrated moral whole' ${ }^{58}$. The stage, however, is marked by legal ambiguities in both the governing treaties of the tunnel and the EU's Schengen rules reviewed earlier. This is combined with a specific geophysical environment which renders any disordered mobilities an immediate obstruction, both literally and symbolically, to the 'smooth operation of infrastructural mobilities' 59 vital to economic competitiveness and cross-border regionalism. Together, then, the uncoordinated efforts of different public and private authorities, media and civil society actors to manage mobility and whereby making borders do not only produce incoherencies in their attempts to harmonise these contradictory rationales, but also foreground tensions and disjunctions within each of them.

\section{Securitising the Channel Tunnel in muddy waters}

It seems evident from the very beginning that logics of security and securitisation have dominated state and private actors' legal, discursive and technical responses to periodic migration 'crises' around the Channel Tunnel. These responses have for example included the additional protocol introduced in 2000 to prevent illegal entries, the increased militarisation of the physical sites around Eurotunnel facilities, and security discourses focused on irregular border-crossing and the transit camp. In the wake of Sangatte, Eurotunnel allegedly spent two million pounds in 2000 enhancing security and surveillance measures by introducing dog patrols and carbon dioxide checks and installing a 6-feet high razor wire fence at the terminals. Speaking of a 'flood of illegal migrants', the company even granted journalists special access to their railway yards in order that they could produce newsworthy images of migrants climbing onto freight trains ${ }^{60}$. To tackle a new episode of 'crisis' in 2014, the UK government offered to send the security fences used at a previous NATO Summit to Calais, and further funded a 13-feet wall to be built near the tunnel entrance in 2016. The spectacle of militarisation, however, goes far beyond the physical sites. Although the camps in Sangatte and Calais have been a major source of security paranoia for Britain, the estimated number of asylum-seekers staying there varies from a few hundreds to a few thousands at different times ${ }^{61}$. This is a mere fraction of the total number of migrant arrivals in countries such as France, Germany and Italy around the same period, and would also make a small proportion of new asylum applications in the UK - if they manage to make the extremely perilous journey through the tunnel. The high visibility of the issue in political discourses and mass media 
has to do with, as Walters observes, the way vehicles and harbours have been contrived as the primary medium of the visual dramatisation of irregular migration, even though illegal entry is not the major 'pathway to irregularity' ${ }^{62}$. The Channel Tunnel, along with the trains and lorries, has in this context provided a focal point for visualising the idea of border threats, which is made real through the circulation of numerous images in newspapers and TV news shows depicting 'would-be' illegal migrants wandering in the terminal area or found hidden under lorries. The images are often accompanied by dehumanising descriptions referring to unauthorised travellers as 'flood' or 'swarm', which have also been used by government ministers. The visual thus 'speak' through interacting with other visuals and textual discourses, and together they 'produce the effects that they name' in the process of 'recitation and repetition' ${ }^{\text {'3 }}$. Most recently, maps and satellite images have become another popular medium of representing and whereby performing border 'crises'. It has been long recognised in critical geography that maps are not merely objective renderings of the world. They are rather expressive and productive of 'socially constructed knowledge', and because of the scientific status of cartography they have the power to naturalise this knowledge and influence 'our imagined geographies' in a subliminal way ${ }^{64}$. With clearly marked custom controls, boarding areas, tunnel entrance as well as locations of security fences, satellite maps such as Figure $1^{65}$ contribute to popular geopolitical imaginations by 'objectively' representing, in details and with precision, the Eurotunnel station located outside the British territory as the national frontier that needs to be secured.

However, local, national and non-state actors involved in securitising the Channel Tunnel borderscapes each construct the meaning of security differently and have a different approach to the relationship between security and other imperatives. Whereas the informal settlement of asylum seekers in the vicinity of the tunnel entrance symbolises an ever-present danger to sovereign border security for the British, it is mainly viewed as a problem of public security on the French side, leading local residents to demand more police forces and national politicians to dispute the division of responsibilities between the two countries ${ }^{66}$. The dramatic encounter at Brussels-Midi station further shows that security actors in Belgium may prioritise Schengen rules rather than British border agents' extraterritorial power in control zones. The conflicting political stakes and uncertain distribution of responsibilities between these managers and regulators of borders are well illustrated by a series of actions taken by Eurotunnel against French and British governments.

Amidst the height of the Sangatte controversy in 2001, the UK Home Office decided to impose a penalty of 2000 GBP per stowaway on Eurotunnel, which could be seen as a tactic of outsourcing sovereign border enforcement to private actors through carrier sanctions. It has been argued that the trend of privatising border security supposedly improves cost-effectiveness by turning 'private actors into regulators' ${ }^{67}$. This logic nonetheless proves less obvious in reality, as private organisations 'do' security work in their own interests and with their own strategic calculations. Eurotunnel's move to allow the press to film in restricted areas, under the circumstances, was part of its campaign against the civil penalty regime. Portraying itself as a victim of Britain's flawed immigration system, Eurotunnel also filed a complaint to the European 
Commission, claiming that the incursions by asylum-seekers 'created an obstacle of the free movement of goods " ${ }^{68}$. After a six-month campaign by the company, the UK government decided to lifted the civil penalty, which according to the Home Secretary was due to a 'dramatic fall in the number of people getting through illegally' ${ }^{69}$. Others suggest that pressures from the French government also 'played a significant role', since the extension of sanctions also effected the Frence-owned $\mathrm{SNCF}^{70}$. Yet Eurotunnel continued its legal action and brought arbitration proceedings before an international tribunal against both governments. The company claimed that both had failed in fulfilling their obligations under the Concession Agreement to protect the Fixed Link from incursions and related damage and expenses, and that the UK government's imposition of civil penalty as well as costs of dentation and removal of migrants on the carrier was another instance of disregarding its obligations under the Agreement. Interestingly enough, France argued that the disruptions caused by migrant incursions were 'vastly exaggerated' by the claimant, and the UK consistently held that combating 'clandestine activity' in or near control zones on the French side was not its responsibility. The tribunal eventually granted partial award to Eurotunnel in 2007, establishing that both governments failed to 'maintain conditions of normal security and public order in and around' the terminal required by the Concession Agreement and recognising the operator's right to compensation ${ }^{71}$. The proceedings document in a detailed way how multiple actors and multiple interests come together to dispute the division of responsibilities for securing the tunnel and to effectively challenge the privatising trend of border security.

\section{Economic reasoning and humanitarian discourse}

Furthermore, economic concerns about whether 'failures' in effective frontier control affect Eurotunnel's revenue and competition with other operators are also a key battleground in the arbitration case. The pursuit of orderly, profitable circulation alongside effective controls is not only a chief goal of the carrier, but indeed the guiding principle of governing cross-border mobility stipulated by the Channel Tunnel treaty. In the Foucauldian sense, the centrality of circulation or 'free movement' is not the antithesis of security but defines the purpose of security politics, which is 'ensuring that things are always in movement' in a way that 'the inherent dangers of this circulation are cancelled out." 72 The material and affective landscapes of the infrastructural space itself embodies this nexus. If the stark militarisation of the terminal areas in Calais and the inhumane conditions of the camp perform an spectacle of sovereign, coercive power that is directed at 'fixing and demarcating the territory" 73 , then the stylish retail units and welcome atmospheres of London St. Pancras perfectly embody the ethos of neoliberal borders which is cultivated through the 'comfy cosmopolitan circuits' of privileged citizens ${ }^{74}$. As P. Adey et al. observe, the staff of the station have worked hard to produce a 'luxuriant atmospheric gateway' to London, or 'positive sense of arrival' wrought by openness and clarity, and the necessity of security and border checks is dealt with 'atmospherically' through floor design and creation of 'shifting aural ambiences" ${ }^{\text {" } 5}$. The affective atmospheres of hospitality and openness, which are even more 'tangible' than in the modern airport isolated from the urban space, work to smooth over interruptions that are necessary for 'cancelling out' the dangers inherent to circulation. Furthermore, the material and affective 'moorings' of comfortable, friction-free mobility not only render the coercive and exclusionary 
dimensions of sovereign border control largely invisible for legitimated travellers, but also strengthen the regime of control by raising the threshold for entering into the circulatory system. Craig Martin makes this point with regard to the well protected vehicle necessitated by accelerated mobility, which according to him is both a 'protective cushion' for privileged travellers and an 'exclusionary divide barring illegitimated peoples' ${ }^{76}$, leading to ever more perilous and violent forms of mobility for the latter ${ }^{77}$.

The ideal balance between border policing and the facilitation of mobility, however, is contingent by nature and constantly subject to unpredictable interruptions. When frictions emerge, economic reasoning may be employed to reinforce the securitisation agenda, as Eurotunnel's strategy demonstrates, or against it, as seen in the French and Belgian reactions to the 'Lille loophole' accident. The Belgian Prime Minister criticised London's decision to suspend through stations by insisting that the move would be of great consequence for the development of the entire Euroregion consisting of Kent, Nord-Pas de Calais, Wallonia and Flanders ${ }^{78}$. Similarly, the French underlined the importance of maintaining 'quality rail services' in Nord-Pas de Calais with regard to its 'specific geography and international positioning' 79. Here the spatial imaginary of the borderland as a Euroregion of 'interregional cooperation and competition across national borders ${ }^{80}$ was explicitly invoked to confront that of 'traditional' statist borders. The troublesome relationship between security and economic reasoning in this context can be intensified by the conflation of the territorial border and the mobility infrastructure itself. This means activities of border transgression, even unsuccessful, involve infiltrating or disrupting the circulatory system upon which capitalist economy depends. An extreme example was an emergency measure called Operation Stack put in place in Kent in the summer of 2015, which was caused by both strikes by French workers and migrant incursions. The prolonged situation of disrupted traffic and was reportedly costing the freight industry ‘ $£ 750,000$ a day’ while the local economy of Kent was 'losing $£ 1.5 \mathrm{~m}$ a day' ${ }^{81}$. On the other hand, any security and immigration requirements would make it less advantageous for the project to realise its economic rationale. In a 2011 report, the House of Lords European Union Committee notes that the border control procedures for Eurostar are already so 'onerous' as to negate 'some of the advantages of train travel over flying, ${ }^{82}$. It also mentions that while Eurostar has sought to extend its service to Germany and the Netherlands, neither country appears friendly to the idea of UKBA officers performing controls on their territory. These concerns prove not unfounded: because of Schengen rules and the characteristics of train travel, passengers travelling from Lyon and Marseille to London have to disembark in Lille and undergo passport control checks, which according to Eurostar may take up to 80 minutes. Eurostar's plan to launch direct service to Amsterdam has also not been materialised so far, perhaps with an even lesser probability to succeed after Brexit. It seems that the national and private border authorities are yet to find a solution to achieve the goal of reconciling efficient controls with the seamlessness of accelerated mobility anticipated in the Channel Tunnel Treaty - at least not on Eurostar.

Lastly, the discourses and practices that engage and reproduce the security/mobility nexus of neoliberal borders also frequently draw on humanitarian reason, which resonates with the increasing 
emphasis on humanitarian and human rights norms in the broader EU border regime and beyond. As researchers of humanitarian borders have explicated, the 'politics of pity' and that of control are not contradictory but mutually constitutive, with 'policing often accompanied by a gesture toward the humane... where force is justified in the name of peace and right' ${ }^{83}$. In governing the borderzone, both British and French governments and Eurotunnel have deployed humanitarian rhetoric to justify the need to demolish the camp and tighten security measures ${ }^{84}$. However, what Fassin terms humanitarian reason, or the moral argument that views 'the preservation of life and the alleviation of suffering as the highest value of action' ${ }^{85}$, and the power of care and control it enables interacts with the sovereign logic of excluding in varied and paradoxical ways. As the archetypical object of humanitarian care, unaccompanied minors in Calais became an urgent issue in the governmental negotiation before the camp was demolished. Again mirroring the EU's incorporation of values of solidarity and humanity as part of its institutional identity, French politicians appealed to these principles and called on their counterpart to deal with the dispute 'in a manner in keeping with the history and the values' of these two countries ${ }^{86}$. The latter's acceptance of 750 unaccompanied minors on the one hand gestured to confirm its 'liberal will-to-care' 87 and seemingly limited its sovereign power for respecting international obligations, yet on the other hand reaffirms the fundamental differentiation at the heart of humanitarian reason - that between those who are worth saving and those not.

It is in this context that the public staging of the 'Lille loophole' becomes especially efficacious in inciting anti-immigration sentiment ${ }^{88}$. Chouliaraki contends that humanitarian sensibility is grounded on a 'theatrical arrangement that separates safe spectators from vulnerable others' and the 'staging of spectacles of suffering, ${ }^{89}$. In a similar fashion, the imaginary of humanitarian borders relies on the existence of two parallel mobilities that are at once incompatible with and interdependent on each other: the accelerated, secured and smooth mobility of legitimated travelers; and the interrupted, dangerous and turbulent (im)mobility of illegitimated ones. The irregular ways of going through the Channel, such as jumping on to trains and hiding in the locked metal compartments or in the lorries, are presented in media as a sheer contrast to the luxuriant and atmospheric style of travel which can be enjoyed with 'breakfast in Brussels, lunch in London, dinner in Paris' and provoke humanitarian sentiment alongside security anxiety. But the carefully balanced and supposedly productive relationship between security, economic and humanitarian rationalities collapses in the 'Lille loophole' scenario. Capsularised mobilities no longer function as an 'exclusionary divide', and the spectacle of suffering is no longer there to cultivate feelings of compassion. It is the safe distance and cruel discontinuity between legitimated and illegitimated means of mobility that guarantees the pitifulness of the latter.

In concluding this section, I would like to mention a European Parliament resolution adopted in the context of the Sangatte dispute. It speaks of the 'deeply damaging' impact the situation has on trade and businesses, calls on governments and carriers to ensure 'effective security measures', spells out the importance of adopting a 'humane' approach to asylum procedures, and urges both the Commission and national governments to ensure free movement of goods among 
Member States as trains from as far as Spain and France are also 'adversely affected'90. All the key themes of EU border governance are neatly weaved into this short text, which both suggests and constructs their institutional and normative compatibility. However, the contingent and uncoordinated responses of national, private and international actors to the episodic migration 'crises' have repeatedly brought about the irreducible contradictions between and within each of these logics. Although governmental technologies such as carrier liability and the affective production of spaces for accelerated mobility are designed to integrate different rationalities into a mutually reinforcing nexus, they are innately challenged by the conflicting interests of multiple actors, legal uncertainties as well as the material properties of the mobile border itself.

\section{From Calais to Dover, or, the politics of turbulent mobilities}

We have thus far mainly taken the perspective of various border authorities - and to a less degree the media - to investigate the laws, discourses and representations they have produced and the political rationalities they perform in bordering the Channel Tunnel. The remainder of the paper briefly considers how turbulent, subversive and violent forms of mobility challenge and interact with the disaggregated regime of border and mobility governance. The camps in and around Calais, which have been demolished by the French police and rebuilt again for several times, have been studied by critical migration scholars as not only spaces of sovereign exception, but also spaces of contestation, solidarity and subjectivisation. These interventions view migrant and solidarity movements as 'acts of citizenship' through which migrants claim the rights to which they have been denied and enact themselves as citizen-subjects ${ }^{91}$. On the other hand, scholars have also cautioned against treating the politics of mobility and the apparatuses of border control as two separate fields and 'analytically privileging one over the other' ${ }^{92}$. Situated in this critical literature, this section focuses on the routes and means of turbulent mobilities, instead of more expressive forms of contestation, and sheds light on how the radical politics of mobility is intricately entangled with the technologies, rationalities and spaces of border governance. I underline in particular how the material characteristics of the moving borders play into this entanglement and can potentially turn the extraterritorial logic of sovereignty against itself.

It needs to be acknowledged that first of all each specific border-crossing from Calais to Dover, whether by high speed train, freight, truck or lorry, is just one among a plurality of choices made according to the migrant's chosen moving strategy ${ }^{93}$. Furthermore, in the same way as the bordering practice is not limited to the territorial borders but expanded both within and outside them, crossing the channel, failed or succeeded, is neither the beginning nor the end of a journey. Making it through the Channel does not necessarily mark the end of illegality or immobility. Due to the lack of sufficient documents, they may still face the possibility of being deported from or detained in their destination country ${ }^{94}$. Nonetheless, as Mezzadra argues, the very act of unauthorised bordercrossing must be understood as a political claim in itself as it undermines the governmental regime and 'constitutes a material critique of the international division of labour and marks profoundly the subjectivity of the migrant also in the country where she/he chooses to settle down' ${ }^{95}$. Such acts 
also expose and intensify the contradictions of the security-economy-humanitarian nexus underpinning the heterogeneous projects of neoliberal bordering; and oblige the assemblage of mobility management to oscillate between practices that put more weight on some logics than others.

However, it is equally important to recognise that strategies of resistance operate 'not just in an extrinsic relationship' to regimes of control, but within them ${ }^{96}$. As shown in the previous sections, the ambiguities of Schengen rules and the multiplicity of actors and interests involved in the bordering of the Channel Tunnel space render this assemblage of actors and rules fragile and contingent upon context-dependent decisions. This fragility has contributed to the existence of 'loopholes' which might be exploited by unauthorised travelers, often in ad hoc and haphazard manners, to achieve short-term goals in flexible life trajectories. Moreover, these subdued forms of resistance are immanent to the border regime also in another sense, namely they involve instrumentally appropriating technologies and rationalities of liberal government such as the commodification of mobility and humanitarian reason. While the supranational, state and non-state authorities engaged in the management of borders cope with the problem of security and circulation through differential commodification of mobility - filtering out or slowing down dangerous forms whereas making desirable and profitable ones as speedy as possible, the smuggling and migrant networks plan their journey through shifting speeds and employ the same logic: 'travelling without frontiers as long as you pay at the start ${ }^{97}$.

The geographical specificities of the mobile border zone and the means of travel play a crucial part in the interplay between mobility governance and the movements that seek to escape its grasp. First, irregular and violent journeys in this context are made possible not only through using illicit networks of commodity mobility, but also by infiltrating, through a kind of "parasitic harnessing', the physical network of infrastructural mobility and vehicular spaces which have been constructed as 'mobile zones of governance' ${ }^{98}$. Secondly, as we have seen, the functional 'fusion' of geographical borders and the transportation network means that turbulent mobilities always contain a potential risk of disrupting the circulatory system far beyond the territorial edge. In the case of Eurostar, the characteristics of train travel and also render it impossible to achieve the goal of filtering out undesirable mobility without introducing 'obnoxious' measures that slow down the whole system designed to embody rapidity. Thirdly, if the trains have been turned into mobile borders through the installation of a 'continuum' of policing, they also become spaces that contain a continuum of potential border-crossing points. It is particularly interesting to consider how the communicative feature of territory is amplified in this dynamics. In his theorisation of territoriality, Sack posits that relations defined in territorial terms are abstract and 'simplistic' compared to those in organic or traditional societies, for communication in the former case requires only 'one kind of marker or sign - the boundary' ${ }^{99}$. As long as the boundaries of modern political community are defined (also) in geographical terms, it is ultimately penetrable. Their geophysicality offers the very condition under which 'the right to escape' can be exercised. In this light, the practice of juxtaposed controls extends not only sovereign power but also the ethical relations implicated by the concept of 
territory beyond the traditional borderline and to the transportation network. This is confirmed in the form of law by attributing the responsibility of processing asylum applications to the country of destination once 'the train doors are closed'. Thus at least in theory an extraterritorial right to asylum is recognised, which generates an indeterminate relationship between those travelling without paper and the territory they are neither 'inside' nor 'outside'.

Comparing to the parasitic harnessing of vehicles, crossing the Channel Tunnel on foot is rare but not non-existent. Most notably two waves of approximately 550 asylum seekers attempted to do so on the Christmas day of 2001, although they were caught by the police soon after they entered the tunnel .In 2015, a Sudanese national named Abdul Rahman Haroun managed to, almost miraculously, walk nearly the entire length of the tunnel after 'climbing four fences, evading international search teams and as many as 400 security cameras ${ }^{\prime 100}$. It must be pointed out that such journeys are fatally dangerous and are a matter of gambling with one's life in a desperate game of 'good chance or no chance' ${ }^{101}$. Without romanticising such choices or reading any emancipatory telos into them, I nonetheless find these acts of resistance extraordinary, in that they not only undermine the apparatus of mobility control but also radically pluralise the meaning of borders and re-shape/scape the borderscapes. As Walters notes, routes and journeys are not just means of transportation; they also provide 'a locus for problematisations of the human and for the possibility of politics ${ }^{\prime 102}$. Whereas the logic of border policing entails turning 'bridges' into borders, this route reverses the logic by exploiting the space of the tunnel itself and staging human agency against its physical environment. Mr. Haroun was eventually able to claim his right to stay by virtue of his territorial presence. Yet successful or not, these turbulent and unsettling movements reinvent by their very existence the constituent meaning inscribed in the structure of a tunnel as a 'connector', and thereby recover the dimensions of territory that communicate and connect from its conceptualisation monopolised by the sovereign state.

\section{Conclusion}

As Darian-Smith has meticulously demonstrated, the English Channel has historically occupied a prominent place in the construction of Britain's insular identity through affective articulations of the relationship between nature and nation. She recalls that on the occasion of the inauguration of the Channel Tunnel in 1994, the then British Prime Minister said in an interview that it was a 'potent symbol of Britain's new role in Europe' ${ }^{103}$. It is perhaps no surprise that as British Prime Minister Theresa May triggered Article 50 to officially start the process of the UK's withdrawal from the EU two decades later, a tabloid newspaper chose to beam 'farewell messages' to their continent neighbours from the iconic white cliffs of Dover. The Channel Tunnel continued to be associated with the imaginary of an ever-present migration problem by both sides in the Brexit debate. While Leave campaigners framed Calais and Eurostar 'loopholes' as indicating a loss of national sovereignty and a need for 'taking back control', politicians advocating for Remain used a similarly scaremongering rhetoric by threatening that leaving the EU would bring the 'Jungle' to Kent. After the vote, France did informally express an intention to close UK border posts on its 
territory, and during his presidential election campaign Emmanuel Macron mentioned that he would renegotiate the border agreement with the $\mathrm{UK}^{104}$. At this stage, the future of juxtaposed controls remains uncertain. However, it is clear that both the Brexit negotiation and any potential bilateral renegotiations will change the legal and institutional frameworks in which the mobile borders are to be governed.

This article has suggested that the border-making projects and their contestations in the Channel Tunnel area constitute both an object of inquiry in its own right and a productive lens for examining some of the key questions emerged from critical scholarship on borders and migration. Approaching borders as institutional and geophysical realities that are constructed through practices, representations and discourses, the article has shown how conflicting visions of the European space and different rationales of mobility governance are intertwined in producing and managing the recurrent migration 'crisis' around the Channel Tunnel. The performances staged by national, local, private and European actors are both influenced by and a condensed expression of the logics of the EU border regime in the wider context. Any general observations or theorisations of EU border politics, however, must be attuned to the specific legal, institutional and material conditions under which the assemblage of mobility takes shape. In scrutinising this case I have paid special attention to legal ambiguities in both Schengen rules and relevant treaties, and how they interact with the materiality of the moving border and mobility routes. The functioning of the transportation network and vehicles as territorial borders - yet providing 'fixed link' to territories of destination - may contingently bring to the fore the communicative capability of territory. The 'landscape' is not only mobilised to generate images of threat and (in)security, but also impacting upon the ways in which turbulent mobilities challenge the apparatuses of border control and disrupt the smoothness of infrastructural mobility.

The inquiry also provides a perspective on the broader question as to how the connective and dividing dimensions of geographical borders might be transformed by infrastructural projects. Comparisons with 'mobile borders' in similar geopolitical contexts such as the Øresund Bridge would make a constructive subject for future research. The bridge has been long considered a successful example of transport infrastructure facilitating cross-border regional integration between Denmark's capital region and South Sweden. However, the Swedish government suspended the Schengen Agreement and put in place passport controls at both ends of the bridge for 15 months amid the recent refugee crisis. The decision has to do with both countries' asylum policies and complicates the characterisation of Øresund as emblematic of a 'borderless Europe' ${ }^{105}$. Furthermore, although this study has focused mainly on issues of border and migration control, this multidisciplinary research agenda will certainly benefit from engaging the debates in other fields such as regionalism, spatial policies and urban development. 


\footnotetext{
${ }^{1}$ G. Keogh, 'Terrorists' fast train to Britain', Daily Mail (23 January 2017), http://www.dailymail.co.uk/news/article4146246/Terrorists-fast-train-Britain.html

${ }^{2}$ For research on the first two aspects see e.g. E. Darian-Smith, Bridging divides: the Channel Tunnel and English legal identity in the new Europe (Berkeley: University of California Press, 1999); M. Sparke, "'Chunnel visions' - Unpacking the anticipatory geographies of an Anglo-European Borderland," Journal of Borderlands Studies 15/1 (2000) pp.187219.

${ }^{3}$ W. Walters, 'Secure borders, safe haven, domopolitics', Citizenship Studies 8/3 (2004) pp.237-260; N. Millner, 'Routing the camp: experiential authority in a politics of irregular migration', Journal of Political Power 6/1 (2013) pp. 87-105.

${ }^{4}$ Conducted by YouGov, https://yougov.co.uk/news/2015/08/09/calais-crisis-french-and-british-support-sending-a/

${ }^{5}$ A. Cooper and C. Perkins, 'Mobile Borders/Bordering Mobilities: Status Functions, Contemporary State Bordering Practices and Implications for Resistance and Intervention', In C. Kinnvall and T. Svensson (eds.), Governing Borders and Security: The Politics of Connectivity and Dispersion (London: Routledge, 2014) p.15.

${ }^{6}$ K. Rygiel, 'Bordering solidarities: migrant activism and the politics of movement and camps at Calais', Citizenship Studies 15/1 (2011) pp.1-19; N. Millner, 'From "refugee” to "migrant" in Calais solidarity activism: Re-staging undocumented migration for a future politics of asylum', Political Geography 30/6 (2011) pp.320-328; D. Fassin, 'Compassion and Repression: The Moral Economy of Immigration Policies in France', Cultural Anthropology 20/3 (2005) pp.362-387.

${ }^{7}$ C. Brambilla, 'Exploring the Critical Potential of the Borderscapes Concept', Geopolitics 20/1 (2015) pp.14-34.

${ }^{8}$ N. Parker and N. Vaughan-Williams, 'Critical Border Studies: Broadening and Deepening the 'Lines in the Sand' Agenda', Geopolitics 17/4 (2012) p.728.

${ }^{9}$ Brambilla (note 7) p. 19.

${ }^{10}$ É. Balibar, We, the People of Europe?: Reflections on Transnational Citizenship (Princeton: Princeton University Press, 2004), p.1.

${ }^{11}$ See e.g., M. B. Sparke, 'A Neoliberal Nexus: Economy, Security and the Biopolitics of Citizenship on the Border', Political Geography 25/2 (2006) pp.151-180; M. Leese and S. Wittendorp (eds.), Security/Mobility: Politics of Movement (Manchester: Manchester University Press, 2017).

${ }^{12}$ A. McNevin, 'Ambivalence and Citizenship: Theorising the Political Claims of Irregular Migrants', Millennium: Journal of International Studies, 41/2 (2013).

${ }^{13}$ This is because the United Kingdom, although a member state of the EU at the time of writing, is not part of the Schengen Agreement that abolished internal border checks between its signatories. This makes the Channel Tunnel and the train stations in Brussels, Paris and Calais the external border-crossing points of the Schengen Area (see Section 2).

${ }^{14}$ M. B. Salter, 'To Make Move and Let Stop: Mobility and the Assemblage of Circulation', Mobilities, 8/1 (2013), p.16.

15 J. Urry, Global Complexity (Cambridge: Polity, 2003); P. Adey, 'If Mobility Is Everything Then It Is Nothing: Towards a Relational Politics of (Im)mobilities', Mobilities, 1/1 (2006):75-94.

${ }^{16}$ V. Squire, 'Acts of Desertion: Abandonment and Renouncement at the Sonoran Borderzone', Antipode 47/2 (2015).

${ }^{17}$ W. Walters, 'Migration, Vehicles, and Politics: Three Theses on Viapolitics', European Journal of Social Theory, 18/3 (2015) p.480.

${ }^{18}$ T. Cresswell and C. Martin, 'On Turbulence: Entanglements of Disorder and Order on a Devon Beach', Tijdschrift Voor Economische En Sociale Geografie 103/5 (2012) p. 516.

${ }^{19}$ Cooper and Perkins (note 5) p.16.

${ }^{20}$ K. Cote-Boucher, F. Infantino, and M. B. Salter, 'Border Security as Practice: An Agenda for Research', Security Dialogue, 45/3 (2014).

${ }^{21}$ Parker and Vaughan-Williams (note 8) p.729.

${ }^{22}$ M. C. Williams, 'Words, Images, Enemies: Securitization and International Politics', International Studies Quarterly, 47 (2003) p.513.

${ }^{23}$ Sparke (note 2); see also Darian-Smith (note 2), Chapter 4.

${ }^{24}$ France No. 1 (1986) Cmnd. 9745.

${ }^{25}$ Treaty Series No. 70 (1993) Cm2366.

${ }^{26}$ Hansard, 16 March 2001, Column 1125.
} 
${ }^{27}$ Treaty Series No. 33 (2002) Cm5015. A tripartite agreement was signed with Belgium in 2004.

${ }^{28}$ B. Ryan and V. Mitsilegas, eds., Extraterritorial immigration control: legal challenges (Leiden: Martinus Nijhoff Publishers, 2010).

${ }^{29} \mathrm{~N}$. Shah, 'The Territorial Trap of the Territorial Trap: Global Transformation and the Problem of the State's Two Territories', International Political Sociology, 6/1 (2012) p.64.

${ }^{30} \mathrm{~J}$. Pugliese, 'Technologies of Extraterritorialisation, Statist Visuality and Irregular Migrants and Refugees', Griffith Law Review, 22/3 (2013): 571-591.

${ }^{31}$ Article 4(4) and Article 13(3), Cmnd. 9745; Clause 14.2, Cmnd. 9769.

${ }^{32}$ Darian-Smith (note 2) p. 216.

${ }^{33}$ Clause 15.2, Cmnd. 9769.

${ }^{34}$ See e.g. C. Rumford, 'Rethinking European Spaces: Territory, Borders, Governance', Comparative European Politics 4/2/3 (2006) pp.127-140; U. Beck and E. Grande, Cosmopolitan Europe (Cambridge: Polity, 2007).

${ }^{35}$ See e.g. H. Leitner, 'Reconfiguring the spatiality of power: the construction of a supranational migration framework for the European Union'. Political Geography 16/2 (1997) pp.123-143; A. Geddes, Immigration and European Integration: Towards Fortress Europe? (Manchester: Manchester University Press, 2000).

${ }^{36}$ Council of the European Union, 'Living in an area of freedom, security and justice'. Brussels, 1 January 2005.

${ }^{37}$ L. Bialasiewicz, S. Elden, and J. Painter, 'The Constitution of EU Territory', Comparative European Politics 3/3 (2005) pp.333-363.

${ }^{38}$ D. Bigo, "Globalized (in)security The field and the ban-opticon," in D. Bigo and A. Tsoukala (eds.) Terror, insecurity and liberty: illiberal practices of liberal regimes after 9/11 (London; New York: Routledge, 2008), pp. 10-48; W. Walters, "Mapping Schengenland: denaturalizing the border," Environment and Planning D: Society and Space 20/5 (2002): 561-580.

${ }^{39}$ Darian-Smith (note 2). See also L. Cawley, 'Rabies and other early Channel Tunnel predictions', BBC News Magazine, http://www.bbc.com/news/magazine-27239849.

40 'the Channel tunnel ... is nothing less than a revolution in habits and practices; ... the whole of Community Europe will have one nervous system and no one country will be able indefinitely to run its economy and its society from the others', quoted in Darian-Smith (note 2) p.2.

${ }^{41}$ P. Thomas and D. O'Donoghue, 'The Channel Tunnel: Transport Patterns and Regional Impacts', Journal of Transport Geography 31 (2013) p.107.

${ }^{42} \mathrm{lbid}$. The geographers point out that the metropolitan centres have been the major beneficiary of the high-speed rail link, whereas its impact on the development of the periphery region has been limited. See also Sparke (note 2).

${ }^{43} \mathrm{G}$. Popescu, 'The Conflicting Logics of Cross-Border Reterritorialization: Geopolitics of Euroregions in Eastern Europe', Political Geography 27/4 (2008) p.423.

${ }^{44}$ Bialasiewicz, Elden, and Painter (note 38).

${ }^{45}$ P. Andreas and T. Snyder, The wall around the West: state borders and immigration controls in North America and Europe (Lanham: Rowman \& Littlefield, 2000).

${ }^{46}$ Document législatif $n^{\circ} 1-396 / 1$, Sénat de Belgique.

${ }^{47}$ For example, on the official webpage introducing the Schengen area, it is stated that 'the Schengen area represents a territory where the free movement of persons is guaranteed'. The Action Plan for the Stockholm Programme claims that 'the Union will pursue an integrated approach to the control of access to its territory in an enlarged Schengen area'.

${ }^{48} \mathrm{~T}$. Christiansen, and K. Erik Jørgensen. "Transnational governance 'above' and 'below' the state: The changing nature of borders in the new Europe." Regional \& Federal Studies 10/ 2 (2000) p.74.

${ }^{49}$ According to the Schengen Border Code, the responsibility of reporting a list of these crossing points to the Commission rests with the Member State.

${ }^{50}$ P. Bonditt, 'From Territorial Space to Networks: A Foucaldian Approach to the Implementation of Biometry', Alternatives: Global, Local, Political 29/4 (2004) p.478.

${ }^{51} \mathrm{Ibid}$.; Paolo Cuttitta, 'Points and Lines: A Topography of Borders in the Global Space', Ephemera: Theory \& Politics in organization 6/1 (2006):27-39.

52 M. Leese, 'Exploring the Security/facilitation Nexus: Foucault at the "smart" Border', Global Society, 30/3 (2016): 412-429; E.-K. Prokkola, 'Technologies of Border Management: Performances and Calculation of Finnish/Schengen Border Security', Geopolitics, 18/1 (2012): 77-94. 
53 Thomas and O'Donoghue (note 41). For a detailed analysis of the case of the Øresund bridge in the context of European space-making, see O. B. Jensen and T. Richardson, Making European space: mobility, power and territorial identity (London: Routledge, 2004).

${ }^{54}$ D. Fassin (note 6).

${ }^{55}$ S. Cox, 'UK border staff in arrest threat over "Lille loophole"', BBC News (8 December 2011), http://www.bbc.co.uk/news/uk-16058860

${ }^{56}$ P. K. Rajaram and C. Grundy-Warr, Borderscapes: Hidden Geographies and Politics at Territory's Edge (Minneapolis: University of Minnesota Press, 2008) p.x; p.xxx.

${ }^{57}$ M. B. Salter, 'To Make Move and Let Stop : Mobility and the Assemblage of Circulation', Mobilities, 8/1 (2013) p.16.

${ }^{58}$ G. Feldman, The Migration Apparatus: Security, Labor, and Policymaking in the European Union (Stanford: Stanford University Press, 2012) p.181.

${ }^{59}$ Cresswell and Martin (note 18) p.516.

${ }^{60}$ S. Pook, 'Help us stop flood of illegal migrants, pleads Eurotunnel', Telegraph 20 Feb 2001. Available at

http://www.telegraph.co.uk/news/uknews/1323396/Help-us-stop-flood-of-illegal-migrants-pleads-Eurotunnel.html; L. Schuster, 'Sangatte: A false crisis', Global Dialogue 4(4) pp.57-68.

61 J. Reinisch, “'Forever Temporary”: Migrants in Calais, Then and Now', Political Quarterly 86/4 (2015) pp.515-522.

${ }^{62}$ Walters (note 17) p. 476.

${ }^{63}$ L. Bialasiewicz et al, 'Performing Security: The Imaginative Geographies of Current US Strategy', Political Geography 26/4 (2007) p.407.

${ }^{64}$ K. Culcasi, 'Cartographically Constructing Kurdistan within Geopolitical and Orientalist Discourses', Political Geography, 25/6 (2006) p.685.

${ }^{65}$ BBC, Channel Tunnel services resume after migrant break-in, 4 October 2015. Available at http://www.bbc.com/news/uk-34432386

${ }^{66} \mathrm{~J}$. Lichfield, 'France calls on Britain to "share” Calais immigrant "burden”', The Independent (12 December 2013), http://www.independent.co.uk/news/world/europe/france-calls-on-britain-to-share-calais-immigrant-burden9001623.html

${ }^{67}$ Cote-Boucher, Infantino, and Salter (note 20) p.196.

${ }^{68}$ S. Scholten, The Privatisation of Immigration Control Through Carrier Sanctions (Leiden: BRILL, 2015) p.232.

${ }^{69}$ Hansard, 4 February 2002, Column 616.

${ }^{70}$ Scholten (note 68), p. 232.

${ }^{71}$ The Channel Tunnel Group Itd and France-Manche Sa v United Kingdom and France, partial

award on Jurisdiction, decision of 30 January 2007.

72 M. Foucault, Security, Territory and Population (Basingstoke: Palgrave Macmillan, 2007) p.93.

${ }^{73}$ Ibid.

${ }^{74}$ Sparke (note 11) p. 169.

${ }^{75}$ P. Adey et al., "'Pour Votre Tranquillité": Ambiance, Atmosphere, and Surveillance', Geoforum, 49 (2013) pp.306307.

${ }^{76}$ C. Martin, 'Desperate Passage: Violent Mobilities and the Politics of Discomfort', Journal of Transport Geography 19 (2011) p.1050.

${ }^{77}$ For example see the field report of Courau: 'Many refugees who managed to climb onto the top of a carriage have been found dead in the Tunnel, electrocuted by the overhead cables. Others have been killed by a passing train or thrown down from the train they had managed to board. Some refugees came back to Sangatte seriously injured, their faces badly lacerated and bruised, their eyes swollen and their clothes covered with blood'. H. Courau, “"Tomorrow Inch Allah, Chance!” People Smuggler Networks in Sangatte', Immigrants \& Minorities 22/2-3 (2003) p.384.

${ }^{78}$ La Libre, 'Di Rupo pour le maintien de l'arrêt des Eurostars à la gare de Lille' (24 February 2012),

http://www.lalibre.be/actu/international/di-rupo-pour-le-maintien-de-l-arret-des-eurostars-a-la-gare-de-lille51b8e69ce4b0de6db9c5b173

${ }^{79}$ Question écrite ${ }^{\circ} 23707$ de M. Jean-Claude Leroy, publiée dans le JO Sénat du 14/06/2012, p.1358.

${ }^{80}$ Sparke (note 2), 194.

81 J. Elgot, How Operation Stack is affecting UK tourism, The Guardian (29 July 2015), https://www.theguardian.com/uk-news/2015/jul/29/how-operation-stack-is-affecting-uk-tourism

82 House of Lords European Union Committee, 'Tunnel vision? Completing the European rail market', 
, 24 $4^{\text {th }}$ Report of Session 2010-12, HL 229, para. 87.

${ }^{83}$ M. Ticktin, Policing and Humanitarianism in France: Immigration and the Turn to Law as State of Exception. Interventions 7/3 (2005) p.359.

${ }^{84}$ Fassin (note 6); Pook (note 60).

85 D. Fassin, 'Humanitarianism: A Nongovernmental Government', in M. Feher (ed) Nongovernmental Politics(New York: Zone Books, 2007) p.151.

${ }^{86}$ B. Cazeneuve, The UK must fulfil its moral duty to Calais's unaccompanied Children. The Guardian (17 October 2016), https://www.theguardian.com/commentisfree/2016/oct/17/uk-moral-duty-calais-unaccompanied-children-asylum

${ }^{87}$ S. M. Reid-Henry, 'Humanitarianism as Liberal Diagnostic: Humanitarian Reason and the Political Rationalities of the Liberal Will-to-Care', Transactions of the Institute of British Geographers, 39/3 (2014) pp.418-431.

${ }^{88}$ Daily Mail was outraged by the fact that one can smuggle themselves into the UK in a 'far more straightforward, and a lot cheaper' way when it was first exposed in 2011. The right-wing tabloid has been so concerned about it that they published a 'demo' trip of a journalist using the 'loophole' to make it to the UK in 2017 (note 1).

${ }^{89}$ L. Chouliaraki, The Ironic Spectator : Solidarity in the Age of Post-Humanitarianism (Cambridge: Polity Press, 2013)

p.27.

${ }^{90}$ European Parliament resolution on the issue of refugees and obstruction of rail freight through the Channel Tunnel, OJ C127 E/690, 29.5.2003.

${ }^{91}$ Rygiel (note 7); Millner (note 7).

${ }^{92}$ Squire (note 16) p.501.

${ }^{93}$ During a trip to Calais in February 2013, a local activist told the author that the average period for which migrants seeking to reach England through the tunnel or by ferries would stay in Calais at that time was around two months. They would then 'try somewhere else, like Dunkirk, or they leave'.

${ }^{94}$ Under the EU's Dublin Regulation, migrants are in principle required to apply for asylum in the first member state they arrive in. This also allows other member states to 'transfer' asylum seekers to the country where they had their fingerprints taken. Hearing my interest in Eurostar, an Afghani asylum seeker laughed and said: 'I met a friend in Rome. He said he sit on top of the train and made it to England. But he was sent back to Italy after that. I never tried because it's too dangerous.' Interview in Calais, February 2013.

${ }^{95}$ S. Mezzadra, 'The Right to Escape', trans. T. Rajanti, Ephemera: Theory \& Politics in Organisation 4 (2004) p.270.

${ }^{96}$ W. Walters, 'Foucault and Frontiers: Notes on the Birth of the Humanitarian Border', In U. Bröckling, S. Krasmann, and T. Lemke (eds.) Governmentality: Current Issues and Future Challenges (New York: Routledge, 2011) p. 153.

${ }^{97} \mathrm{G}$. Verstraete, 'Technological frontiers and the politics of mobility in the European Union', In S. Ahmed, C. Castaneda, A. M. Fortier \& M. Sheller (eds.), Uprootings/Regroundings: Questions of Home and Migration (London: Berg, 2004) p244.

${ }^{98}$ Walters (note 17) p.473; Martin (note 76).

${ }^{99}$ R. Sack, Human Territoriality: Its Theory and History (Cambridge: Cambridge University Press, 1986) p.32.

${ }^{100}$ D. Bilefsky, 'In a First, a Sudanese Migrant Nearly Crosses the English Channel on Foot', New York Times (7 August 2015), https://www.nytimes.com/2015/08/08/world/europe/channel-tunnel-sudanese-migrant.html.

${ }^{101}$ As the Good Chance Theatre reveals, 'good chance or no chance' is a popular phrase among the residents of the Calais 'Jungle' to mean the likelihood of crossing the border 'on a given night', http://goodchance.org.uk/about/.

102 Walters (note 17) p.472.

${ }^{103}$ Darian-Smith (note 2) p.75.

104 J. Kirkup, 'David Cameron says Brexit would bring a migrant 'Jungle' to Kent: what are the facts'? The Telegraph (8 February 2016), http://www.telegraph.co.uk/news/newstopics/eureferendum/12146463/David-Cameron-says-Brexitwould-bring-a-migrant-Jungle-to-Kent-what-are-the-facts.html; G. Rayner, 'Macron wants to renegotiate Calais border treaty', The Telegraph (28 April 2017), http://www.telegraph.co.uk/news/2017/04/28/emmanuel-macron-wantsrenegotiate-calais-border-treaty/.

105 Jensen and Richardson (note 53). 